21. Bradley M. M. The international affective picture system (IAPS) in the study of emotion and attention in: Handbook of Emotion Elicitation and Assessment (eds.) / M. M. Bradley, P. J. Lang ; Oxford Univ. Press. Oxford ; New York, 2007. - P. 29-46.

22. Abbassi E. Processing the emotions in words: The complementary contributions of the left and right hemispheres / E. Abbassi, K. Kahlaoui // Cogn Affect Behav Neurosci. - 2011 - Sep; 11(3). - P. $372-85$.

23. Compton R. Paying attention to emotion: An fMRI investigation of cognitive and emotional Stroop tasks / R. Compton // Cogn Affect Behav Neurosci. - 2003. - 3(2). - P. 83-84; 87-93.

24. Davidson R. Anterior cerebral asymmetry and the nature of emotion / R. Davidson // Brain and Cognition. 1992. - 20. - P. 125-151.

25. Engel A. Beta-band oscillations-signalling the status quo? / A. Engel, P. Fries // Curr Opin Neurobiol. - 2010. 20(2). - P. 156-165.

26. Putman P. EEG theta/beta ratio in relation to fear-modulated response-inhibition, attentional control, and affective traits / P. Putman, van J. Peer, I. Maimari, van der S. Werff // Biol Psychol. - 2010. - Feb. - 83(2). - P. 73-8.

27. Rassomagina M. Electrical brain activity during monocular presentation of verbal stimuli in the emotional Stroop-test / M. Rassomagina, V. Kravchenko // Visnyk of Taras Shevchenko Kyiv National University. Problems of regulation of physiological functions. - 2013. - 16. - P. 37-41.

28. Kutcenko T. Learning effect during repeatedly passing emotional Stroop test / T. Kutcenko, N. Fylymonova, O. Novycka // Visnyk of Taras Shevchenko Kyiv National University. Biology. - 2010. - 55. - P. 30-32.

Бондаренко (Рассомагина) Мария, Бондаренко Александр, Кравченко Виктория, Макарчук Николай. ЭЭГ анализ распределения внимания у левшей и правшей при прохождении эмоционального Струптеста на фоне изображений ИАPS. Оценивали спектральную мощность и коэффициент когерентности основных ритмов ЭЭГ (тета, альфа, бета-низкочастотный, бета-высокочастотный) во время эмоционального Струп-теста на фоне изображений ИАРS у левшей и правшей с открытым доминантным и недоминантным глазом. Информация, попадающая в анализирующие структуры головного мозга через доминантный зрительный канал, анализируется быстрее, чем при восприятии через недоминантный зрительный канал, что характерно только для левшей. Были показаны достоверные изменения ЛП реакции недоминантной руки на нейтральные слова и доминантной руки на эмоциональные слова как для правшей, так и для левшей. Согласно ЭЭГкоррелятов эффект обучения прослеживается при восприятии информации через левый глаз как для левшей, так и для правшей.

Ключевые слова: ИAPS, эмоциональный Струп-тест, доминантный глаз, недоминантный глаз.

Bondarenko (Rassomagina) Maria, Bondarenko Alexander, Kravchenko Victoriya, Makarchuk Mukola. EEG Analysis of the Distribution of Attention in Left-handers and Right-handers During Emotional Stroop-test on the Background of IAPS Images. Evaluated spectral power and coherence factor of the main EEG rhythms (theta, alpha, beta low-frequency, beta high-frequency) during the emotional Stroop-test on the background of IAPS images in left-handers and right-handers during perception through dominant and nondominant eye. Information that comes to analyzing structures of the brain through the dominant visual channel analyzed faster than that comes through the nondominant visual channel that is typical only for left-handers. Significant changes were shown for LP reactions of the nondominant hand on the neutral words and the dominant hand on the emotional words for both right-handers and left-handers. According to the EEG-correlates learning effect is present during perception of information through the left eye for left-handers and right-handers.

Key words: IAPS, emotional Stroop-test, dominant eye, nondominant eye.

Стаття надійшла до редколегії

08.11.2015 p.

УДК 636.4:612.017:612.176:547.992:577.164.2

Оксана Бучко

\title{
Вільнорадикальні процеси в організмі свиней під дією біологічно активних добавок
}

Біологічно активна добавка «Гумілід» у комплексі з аскорбіновою кислотою викликає гальмування вільнорадикальних процесів (зниження вмісту гідропероксидів ліпідів, карбонільних груп протеїнів і ТБК-активних

() Бучко O., 2015 
продуктів) та стимулювання системи антиоксиданого захисту (підвищення активності супероксиддисмутази й каталази) в крові свиноматок та новонароджених поросят.

Ключові слова: свиноматки, поросята, критичні періоди онтогенезу, адаптаційна здатність організму, «Гумілід», аскорбінова кислота

Постановка наукової проблеми та ї̈ значення. Підвищення адаптаційної здатності та збереженості високопродуктивних тварин й особливо молодняку в умовах промислового вирощування за допомогою біологічно активних речовин належить до найбільш актуальних науково-практичних проблем. Науковці розробляють нові ефективні вітчизняні препарати природного походження, які володіють антиоксидантною та імуномодулюючою дією на організм тварин і не шкодять кінцевому споживачеві - людині. Для пом'якшення дії різноманітних стресів у тваринництві, у тому числі під час поросності у свиноматок та постнатальної адаптації в поросят, актуальним є використання екологічно чистих, низькотоксичних і високоефективних препаратів, які можна давати тваринам із кормом [10; 11 ; $16 ; 18,233-240 ; 22,12-17]$.

Одним із найбільш перспективних напрямів профілактики негативних наслідків стресу й підвищення адаптаційної здатності організму $є$ вживання біологічно активних речовин гумінової природи. Висока екологічна безпека гумінових речовин та унікальна здатність покращувати обмінні процеси, підвищувати енергетику клітин і проявляти імуномодуляційні властивості надзвичайно позитивно впливає на живі організми. Як засвідчили дослідження $[4 ; 8 ; 12 ; 24]$, гумати здатні іммобілізувати сполуки і неорганічної, і органічної природи, проявляючи властивості хелатних лігандів та вступаючи в процеси комплексоутворення. Будучи біологічно активними сполуками, гумінові речовини при специфічній у кожному конкретному випадку обробці можуть бути джерелом нових різноманітних біологічно активних речовин, що використовується науковцями для виготовлення на їх основі препаратів різноманітного спектра дії. В організмі вони виконують унікальну функцію із підтримки постійності внутрішнього гомеостазу біосистеми на тканинному, клітинному й субклітинному рівнях, сприяючи відновленню фізіологічних функцій при патологічних станах і в екстремальних ситуаціях [2;9].

Як зазначено в наукових дослідженнях, стресові ситуації, порушення обміну речовин, дефіцит у раціоні вуглеводів, протеїну, вітамінів $\mathrm{A}, \mathrm{E}, \mathrm{B}_{2}, \mathrm{~B}_{3}$, гормональні дисфункції, хвороби шлунковокишкового тракту та печінки, висока продуктивність порушують синтез одного з найважливіших антиоксидантів організму - аскорбінової кислоти $[15 ; 17 ; 21]$. Тому, особливо в критичні періоди онтогенезу, для підвищення антистресових властивостей організму в раціони уводять добавку віт. С, що послаблює або навіть виключає негативний вплив стрес-факторів, сприяє збереженню молодняку та підвищенню продуктивності тварин. Згідно 3 нашими й літературними даними, додаткове включення аскорбінової кислоти до раціону поросних свиноматок сприяє активації імунітету та кращому виживанню новонароджених, а також підвищенню приростів живої маси й нормалізації біохімічних показників у крові відлучених поросят [3; 10; 20].

Мета роботи - з'ясувати вплив біологічно активної кормової добавки гумінової природи та аскорбінової кислоти на показники оксидативного стресу й антиоксидантної системи організму свиней під час критичних періодів онтогенезу - лактації у свиноматок і ранньої постнатальної адаптації в поросят.

Матеріали й методи. Дослідження проведено на свиноматках великої білої породи та народжених від них поросятах. За принципом аналогів сформовано дві групи тварин - контрольну й дослідну (по п'ять голів у кожній). Годівляю тварин проводили вволю, із вільним доступом до кормів і води. За 10 діб до опоросу один раз на добу свиноматкам дослідної групи (СВ Д) до раціону додавали $1 \%$ розчин біологічно активної кормової добавки «Гумілід» (ТУ У 15.7-00493675-004:2009) з розрахунку 0,5 мл/кг живої маси, а також аскорбінову кислоту в кількості 2,5 мг/кг живої маси (період згодовування добавок - 10 діб). Свиноматок контрольної групи (СВ К), а також поросят, народжених від свиноматок дослідної (ПД) та контрольної (ПК) груп утримували на стандартному раціоні. Весь період досліджень - 31 доба. Під час проведення досліджень дотримувалися «Загальних етичних 
принципів експериментів на тваринах», ухвалених Першим Національним конгресом із біоетики (Київ, 2001).

Матеріалом для дослідження слугувала кров свиноматок, отримана з очної вени за 10 діб до і на п’яту та 21 добу після опоросу. У поросят, народжених від свиноматок обох груп, кров відбирали 3 передньої порожнистої вени у 5- і 21-добовому віці. Визначення показників антиоксидантного статусу та вільнорадикальних процесів проводили на спектрофотометрі Unico 1205 (США). Стан антиоксидантної системи в загальних гемолізатах еритроцитів крові тварин визначали загальноприйнятими методами за активністю супероксиддисмутази (СОД; 1.15.1.1) й каталази (КАТ; 1.11.1.6) [5, 359-363]. Уміст показників оксидативного стресу в плазмі крові свиноматок і поросят обчислювали за загальноприйнятими методами відповідно до концентрації ТБК-активних продуктів, карбонільних груп протеїнів (КГП) та гідропероксидів ліпідів (ГПЛ) [5, с. 356-358, 166-167].

Результати досліджень опрацьовували статистично з використанням середнього арифметичного інтервалу для оцінки $(M \pm m)$ й інтервалу для оцінки ступеня вірогідності $(p)$ за допомогою Стьюдента. Розбіжності вважали статистично вірогідними при $P \leq 0,05$.

Виклад основного матеріалу й обгрунтування отриманих результатів дослідження. 3 огляду на проблему підвищення продуктивності та збереженості високопродуктивних тварин потрібно приділяти велику увагу вивченню обмінних процесів в організмі тварин на рівні взаємодії «організм матері-плід-новонароджена тварина» на фоні метаболізму в поросних і лактуючих свиноматок, а також новонароджених поросят, тобто в найбільш критичні періоди онтогенезу. Рівень адаптаційної здатності поросят раннього віку, їх ріст і збереженість, передусім, залежать від ефективності функціонування захисних сил та рівня метаболічних процесів в організмі свиноматок, що, зі свого боку, нерозривно пов'язано 3 адекватним забезпеченням матерів необхідними біологічно активними речовинами, особливо в період поросності $[14 ; 18]$.

Дані літератури свідчать, що другий період поросності (із 85 до 114 доби) у свиноматок характеризується підвищеним обміном речовин і збільшенням потреби в енергії в декілька разів [16; 22 , 268-291]. Ці зміни пояснюють тим, що значно більше енергії й поживних речовин свиноматка витрачає на формування плода. Для цього періоду характерні великі витрати, пов'язані з використанням субстратних та енергетичних речовин, а дефіцит у раціоні необхідної кількості енергії призводить до метаболічних порушень в організмі свиноматки й активації руйнівної дії вільнорадикальних процесів у клітинах. Як наслідок, виникає оксидативний стрес, який, у підсумку, може викликати зниження плодючості та збільшення нежиттєздатного приплоду [2; 10; 11$]$.

Під час досліджень установлено, що поросність свиноматок супроводжується високою інтенсивністю оксидативних процесів у їхній крові. Так, за 10 діб до опоросу в плазмі крові контрольної та дослідної груп тварин установлена висока концентрація як початкових (ГПЛ), так і кінцевих (ТБКактивні продукти) метаболітів перекисного окиснення ліпідів (ПОЛ), а також продуктів вільнорадикального пошкодження протеїнових молекул - КГП. У свиноматок контрольної групи високий рівень продуктів вільнорадикальних реакцій спостерігали й на п’яту добу після опоросу, стосовно вихідного рівня, що є підтвердженням стану оксидативного стресу, у якому перебувають матері відразу після народження поросят (рис. 1-3).

На 21 добу після опоросу в крові свиноматок обох груп установлено вірогідне зниження вмісту ГПЛ відносно початку досліджень в 1,3 раза, ТБК-активних продуктів - в 1,6 та КГП - в 1,9 раза (рис. 1-3), що засвідчує нормалізацію процесів пероксидації в організмі тварин у цей період.

Із літературних джерел відомо, що процес переходу від внутрішньоутробного розвитку до постнатального за глибиною впливу відносять до стресу $[1,21]$. У цей час відбувається становлення основних фізіологічних функцій і перехід на автономне дихання, розвивається транзиторна втрата маси тіла, виникають явища гормональної кризи, інтенсивне функціонування й ріст органів супроводжується значним посиленням процесів дихання, інтенсивним надходженням і поглинанням кисню організмом. Уважається, що адаптивна перебудова в організмі новонароджених тварин, яка пов'язана 3 пристосуванням до нових умов життя й харчування, закінчується до 2-місячного віку формуванням повноцінно функціонуючої системи АОЗ [10; 11]. 


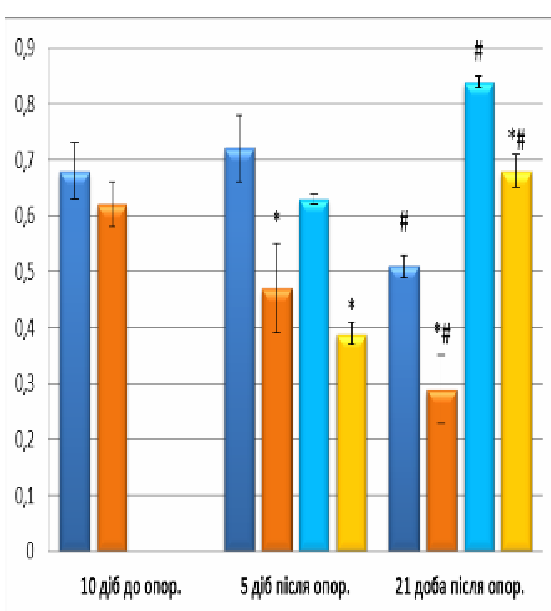

Рис. 1. Уміст ГПЛ у плазмі свиней $($ OE/мл; $M \pm m ; n=5)$

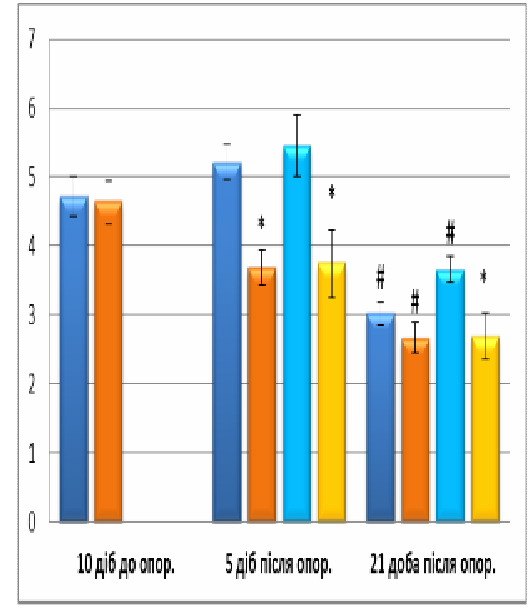

Рис. 2. Уміст ТБК-активних продуктів у плазмі свиней (нМоль/мл; $M \pm m ; n=5)$

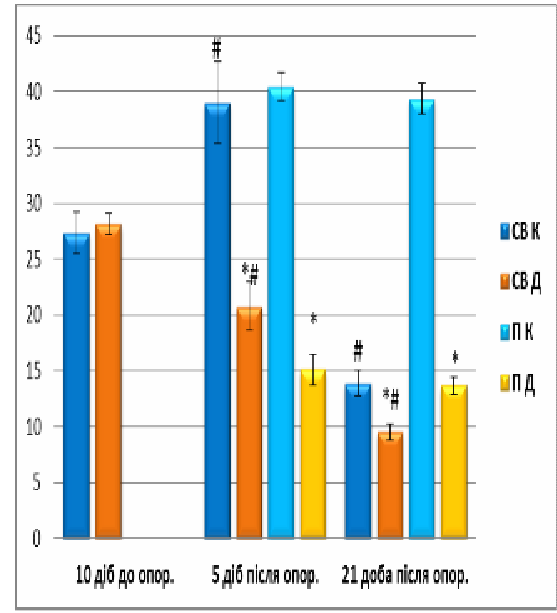

Рис. 3. Уміст КГП у плазмі свиней (нМоль/мг прот.; $M \pm m ; n=5)$

Примітка. У рисунках: статистично вірогідні різниці порівняно з контрольною групою тварин $*-p \leq 0,05$; статистично вірогідні різниці в межах кожної групи, порівняно з початком досліджень ${ }^{*}-p \leq 0,05$.

Дослідженнями встановлено високий рівень показників оксидитивного стресу в крові поросят контрольної групи протягом перших 21 діб життя. Особливо високою була концентрація ГПЛ (в 1,3 раза стосовно 5-добового віку) і КГП (упродовж усього періоду досліджень) (рис. 1, 3), що свідчить про наявність стресу та, як наслідок, пошкодження ліпідних і протеїнових компонентів організму новонароджених тварин $[1 ; 13 ; 19]$. Ці дані підтверджують літературні показники про зміщення співвідношення між вільнорадикальними процесами й станом АОЗ в організмі поросят після народження в сторону активації процесів пероксидації [10].

У зв'язку з отриманими даними важливе місце займає проблема пошуку та використання засобів, які зменшують вплив стрес-факторів на організм як свиноматок, так і новонароджених поросят, за допомогою неспецифічної дії, спрямованої на поліпшення обміну речовин, активацію адаптивних та саморегуляторних реакцій різних систем $[2 ; 15]$. За цих умов зростає біологічне значення гумінових сполук і віт. С як речовин профілактичної, імуностимуляційної й антиоксидантної дії.

У результаті досліджень установлено, що комплексне уведення до основного раціону свиноматок Гуміліду і віт. С викликало зменшення вмісту в крові тварин продуктів кисневого пошкодження, як ліпідних, так і білкових молекул. Виявлено вірогідне зниження концентрації ГПЛ у плазмі крові свиноматок і поросят дослідних груп, порівняно з контролем. У СВ Д їх рівень спадав на 5-ту й 21 добу після опоросу в 1,5 та 1,7 раза. Потрібно зауважити, що у СВ Д протягом періоду досліджень рівень згаданих метаболітів вірогідно знижувався, порівняно з 10 добою перед опоросом (на 21 добу після опоросу - удвічі). У крові 5- і 21-добових ПД уміст ГПЛ в 1,6 та 1,2 раза нижчий відносно П К (рис. 1).

Стосовно ТБК-активних продуктів за дії досліджуваних біологічно активних добавок установлено вірогідне зниження їх концентрації, порівняно з контрольними тваринами, у СВ Д на п’яту добу після опоросу в 1,4 раза. На 21 добу після опоросу рівень згаданих метаболітів ПОЛ у крові СВ Д у межах групи спадів 1,7 раза, порівняно з початком досліджень. У 5- й 21-добових П Д концентрація ТБКактивних продуктів знижувалася відповідно до контролю в 1,4 раза (рис. 2).

Гумінова добавка та аскорбінова кислота викликали вірогідне зниження вмісту КГП як в організмі свиноматок дослідної групи, так і в крові народжених від них поросят, порівняно 3 контрольною групою тварин. Так, у СВ Д рівень досліджуваних метаболітів пошкодження протеїнових молекул знижувався в 1,8 раза на п'яту й в 1,4 раза на 21 добу після опоросу відповідно до контролю, спадаючи втричі в межах групи, порівняно з 10 добою до опоросу. Стосовно 5- та 21-добових П Д, то в їхній крові спостерігали зниження рівня КГП у 2,7 і 2,8 раза, порівняно з ПК (рис. 3). 
Отже, результати дослідження підтвердили дані інших науковців $[4 ; 8 ; 7 ; 21]$ про те, що макромолекули гумінових кислот та аскорбінова кислота, підсилюючи дію один одного, здатні безпосередньо діяти як антиоксиданти, а саме бути донорами електронів для вільних радикалів, відновлюючи їх і перетворюючи на молекулярні речовини, обриваючи тим самим ланцюг вільнорадикальних реакцій та знижуючи в організмі тварин кількість продуктів ПОЛ й окисної модифікації протеїнів.

Система АОЗ контролює та підтримує стаціонарний рівень вільнорадикальних процесів в організмі й установлює оксидантно-антиоксидантну рівновагу $[6 ; 20]$. Ланка антиоксидантних реакцій у механізмі захисних процесів $є$ провідною та найбільш потужною, оскільки вони запобігають не лише розвитку вільнорадикальних реакцій, накопиченню супероксиданіонів та пероксидів, але й підтримують високу активність окисно-відновних процесів, забезпечують елімінацію кінцевих кисневих метаболітів із їх залученням до енергетичного обміну та активації процесів синтезу [1;23]. Дані про особливості функціонування системи АОЗ залежно від віку й фізіологічного стану слід ураховувати при забезпеченні збереження та захисту здоров'я тварин. Відношення показників стану антиоксидантної системи й інтенсивності процесів пероксидації - об'єктивний критерій оцінки антиоксидантного статусу та рекомендується для своєчасного виявлення оксидативного стресу в організмі тварин [2; 11].

Систему AO3 на рівні цілого організму представлено еритроцитарними ензимами, уключаючи СОД і КАТ у якості початкового ланцюга захисту від супероксиданіонрадикалів і пероксиду водню. Дослідження підтвердили, що стан оксидативного стресу, у якому перебувають матері відразу після народження поросят, характеризується низькою активністю антиоксидантних ензимів, особливо в крові свиноматок контрольної групи впродовж дослідного періоду (рис. 4; 5).

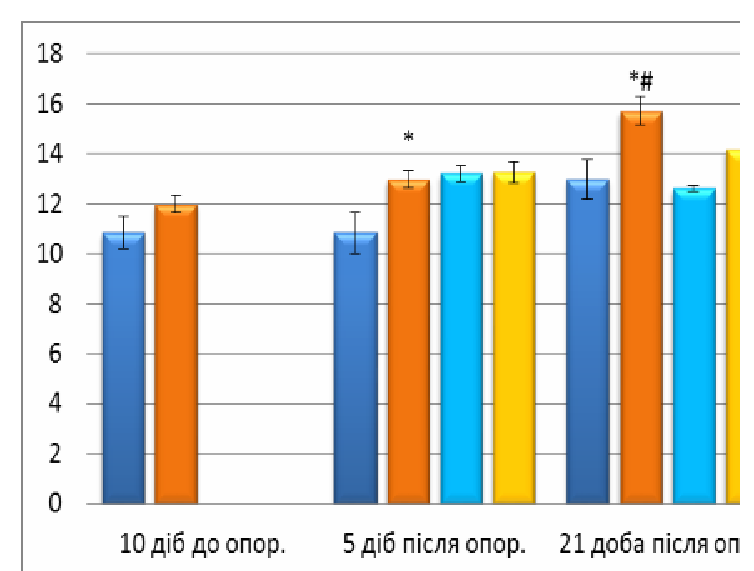

Рис. 4. Активність СОД в еритроцчитах свиней (\%/мл; $M \pm m ; n=5)$

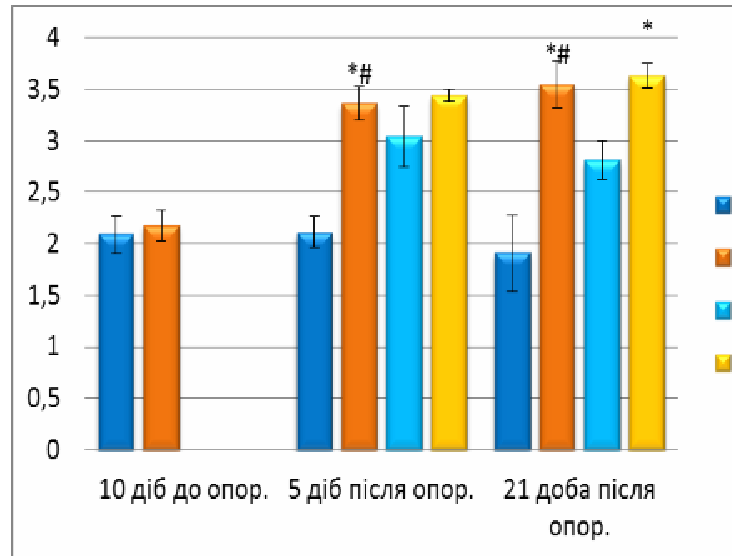

Рис. 5. Активність КАТ в еритроцичтах свиней (мМоль/хвхиг прот.; $M \pm m ; n=5$ )

Про інтенсивний рівень процесів пероксидації в організмі поросят до 21-добового віку свідчить низька активність СОД і КАТ (рис. 4; 5), особливо в еритроцитах крові тварин контрольної групи, що пояснює встановлену високу концентрацію продуктів вільнорадикального пошкодження протеїнових і ліпідних компонентів (ГПЛ та КГП) (рис. 1; 3).

Логічно припустити, що, проявляючи антиоксидантні властивості, гумати й віт. С повинні підвищувати активність системи АОЗ організму свиней у критичні періоди опоросу й постнатальної адаптації. У ході досліджень установлено вірогідне підвищення активності ключового ензиму цієї системи - СОД в еритроцитах крові свиноматок і поросят під впливом досліджуваних добавок. Так, на 5-ту й 21 добу після опоросу спостерігають зростання його активності в СВ Д в 1,2 раза відносно СВ К. У 21-добових П Д активність СОД підвищувалася на 12 \% стосовно П К (рис. 4). Зростання активності досліджуваного ензиму під дією гумінової добавки можна пояснити іï здатністю до хелатоутворення з мікроелементами Купруму й Цинку, які входять до активного центру СОД [4; 9]. 
Гумілід та аскорбінова кислота підвищували активність ще одного ензиму САЗ організму свиноматок і поросят - КАТ. На 5-ту й 21 добу після опоросу у СВ Д установлено вірогідне зростання його активності стосовно СВ К в 1,6 та 1,8 раза. У 21-добових П Д активність КАТ підвищувалася в 1,3 раза відносно П К (рис. 5). Компенсаторне підвищення активності досліджуваного ензиму можна пояснити стимулюванням його синтезу, оскільки під дією аскорбінової кислоти відбувається краще засвоєння організмом Феруму, що входить до активного центру КАТ [6].

Слід зауважити, що в крові СВ Д на 21 добу після опоросу активність СОД вірогідно зростала в 1,3 раза, а КАТ - в 1,6 раза, порівняно з величиною до опоросу, тоді як у СВ К активність обох досліджуваних ензимів залишалася на одному рівні впродовж дослідного періоду (рис. 4; 5), що може свідчити про кращу післяродову відновлювану й адаптаційну здатність матерів за дії «Гуміліду» та аскорбінової кислоти.

Отже, у ході досліджень підтверджено здатність гумінової сполуки в комплексі з віт. С проявляти антиоксидантну дію: переривати ланцюговий процес біокаталізу, рекомбінувати 3 проміжними вільними радикалами, нейтралізувати їх i, таким чином, гальмувати утворення продуктів вільнорадикальних реакцій $[7 ; 8]$. Гумати, володіючи хелатоутворенням, а саме маючи можливість утворювати стійку сполуку з мікроелементами (Цинком, Ферумом, Купрумом) та підвищуючи стабілізацію й засвоєння організмом вітамінів-антиоксидантів (у тому числі й віт. С) стимулюють активність $\mathrm{i}$ синтез ензимів та метаболітів АОЗ організму [12; 17; 20; 24].

Вищу антиоксидантну активність у крові поросят дослідної групи можна пояснити надходженням досліджуваних добавок через плаценту й формуванням у плода ще в лоні матері, а потім і через молоко вищої адаптаційної здатності організму. Комплекс Гуміліду з віт. С пропонуємо розглядати як імуномодулятори та адаптогени й використовувати в критичні періоди онтогенезу для зменшення дії стресових чинників на організм тварин.

Висновки й перспективи подальших досліджень. Додавання до стандартного раціону свиноматок перед опоросом комплексу аскорбінової кислоти з біологічно активною кормовою добавкою «Гумілід» викликає в крові матерів і народжених від них поросят: КГП);

1) гальмування вільнорадикальних процесів (зниження вмісту ГПЛ, ТБК-активних продуктів,

2) активацію системи АОЗ (підвищення активності СОД і КАТ);

3) пролонговану дію (після припинення згодовування добавок підтримання досліджуваних показників на високому рівні до 21 доби після опоросу у свиноматок і 21-добового віку в поросят, порівняно з контролем).

Перспективними будуть дослідження зі встановлення особливостей комплексного впливу досліджуваних біологічно активних добавок на інші ланки обміну речовин у тварин у критичні періоди онтогенезу.

\section{Джерела та література}

1. Барабой В. А. Стресс: природа, биологическая роль, механизмы, исходы / В. А. Барабой - Киев : Фитосоциоцентр, 2006. - 424 с.

2. Бузлама С. В. Фармакология препаратов гуминовых веществ и их применение для повышения резистентности и продуктивности животных : автореф. дис. ... д-ра вет. наук / С. В. Бузлама. Воронеж, 2008. - $40 \mathrm{c}$.

3. Бучко О. М. Метаболізм в організмі поросят за дії аскорбінової кислоти / О. М. Бучко, Н. О. Салига, О. 3. Сварчевська // Біологія тварин. - 2014. - Т. 16, № 3. - С. 161.

4. Комиссаров И. Д. Биологическая активность гуминовых препаратов / И. Д. Комиссаров // Досягнення та перспективи застосування гумінових речовин у сільському господарстві. - Дніпропетровськ : [б. в.], 2008. - C. 75-78.

5. Лабораторні методи досліджень у біології, тваринництві та ветеринарній медицині / В. В. Влізло, Р. С. Федорук, І. Б. Ратич [і ін.] - Львів : СПОЛОМ, 2012. - 762 с.

6. Попова Л. Д. Вплив аскорбінової кислоти на активність ферментів антиоксидантної системи і по-синтази крові морських свинок / Л. Д. Попова, І. М. Васильєва // Медицина сьогодні і завтра. - 2010. - № 23 (47-48). - C. $72-74$.

7. Смирнова О. В. Совместное действие аскорбиновой и гуминовой кислот в процессах радикально-цепного окисления / О. В. Смирнова, И. В. Ефимова, С. Л. Хилько и др. // Наносистеми, наноматеріали, нанотехнології. - 2010. - Т. 8, № 4. - С. 843-849. 
8. Степченко Л. М. Регуляторні механізми дії біологічно активних речовин гумінової природи на організм продуктивної птиці / Л. М. Степченко // Фізіологічний журн. - 2010. - Т. 56, № 2. - С. 306.

9. Томсон А. Э. Антиоксидантная активность препаратов из торфа и растительного сырья / А. Э. Томсон, Г. В. Наумова, С. Ф. Шурхай и др. // Природопользование. - 2011. - Вып. 19. - С. 165-169.

10. Чумаченко В. В. Біохімічні та імунологічні основи системи профілактики стресу в свиней : автор. дис. ... д-ра вет. наук / В. В. Чумаченко. - К., 2007. - 24 с.

11. Ярован Н. И. Биохимические аспекты оценки, диагностики и профилактики технологического стресса у сельскохозяйственных животных : автореф. дис. ... д-ра биол. наук / Н. И. Ярован. - М., 2008. - 41 с.

12. Bittner M. Direct effects of humic substances on organisms / M. Bittner. - Brno : Czech Republic, 2006. - 31 p.

13. Buttke T. M. Oxidative stress as a mediator of apoptosis / T. M. Buttke, P. A. Sandstrom // Immunol. Today. 1994. - № 15. - P. 7-10.

14. Farmer C., Quesnel H. Nutritional, hormonal, and environmental effects on colostrum in sows / C. Farmer, H. Quesnel // J. ANIM. SCI. - 2009. - Vol. 87, №. 13. - P. 56-64.

15. Frei B. Vitamin C and cancer revisited / B. Frei, S. Lawson // Proc. Natl. Sci. USA. - 2008. - Vol. 105, №. 32. P. 11037-11038.

16. Hansen A. V. Effects of nutrient supply, plasma metabolites, and nutritional status of sows during transition on performance in the next lactation / A. V. Hansen, C. Lauridsen, M. T. Sørensen et al. // J. ANIM. SCI. 2012. - Vol. 90, №. 2. - P. 466-480.

17. Hasselholt S. Vitamin C: its role in brain development and cognition / S. Hasselholt, P. Y. Tveden-Nyborg, J. Lykkesfeldt // Nutr. Cogn. Perform.: Dev. Perspect. - 2011. - P. 29-52.

18. Kolacz R. Higiena i dobrostan awierzat gospodarskich / R. Kolacz, Z. Dobrzanski. - Wroclaw : WAR, 2006. $537 \mathrm{p}$.

19. Koshoridze N. I. Quantitative Alterations in the Products of Lipid Peroxidation under Stress / N. I. Koshoridze, K. O. Menabde, Z. T. Kuchukashvili et al. // Journal of Stress Physiology \& Biochemistry. - 2010. - Vol. 6, №. 2. - P. 4-9.

20. Lindblad M. Regulation of Vitamin C Homeostasis during Deficiency / M. Lindblad, P. Tveden-Nyborg, J. Lykkesfeldt // Nutrients. - 2013. - № 5. - P. 2860-2879.

21. Maya D. Paidi Prenatal vitamin C deficiency results in differential levels of oxidative stress during late gestation in foetal guinea pig brains / Maya D. Paidi, Janne G. Schjoldager, Jens Lykkesfeldt et al. // Redox Biology. - № 2. - 2014. - P. 361-367.

22. Pejsak Z. Choroby swin / Z. Pejsak. - Poznan : Pol. Wyd. Rol., 2002. - 353 p.

23. Sahin E. Immobilization stress in rat tissues: Alterations in protein oxidation, lipid peroxidation and antioxidant defense system / E. Sahin, S. Gumuslu // Comp. Biochem. Physiol. Part C: Toxicol. Pharmacol. 2007. - Vol. 144, №. 4. - P. 342-347.

24. Trckova M. Peat as a feed supplement for animals: a review / M. Trckova, L. Matlova, H. Hudcova et al. // Vet. Med. - Czech. - 2005. - Vol. 50, №. 8. - P. 361-377.

Бучко Оксана. Свободнорадикальные процессы в организме свиней под влиянием биологически активных добавок. В статье раскрывается вопрос повышения адаптационной возможности организма высокопродуктивных животных в условиях интенсивных технологий выращивания в наиболее критические периоды их развития - супоросности, лактации и новорожденности. Анализируется комплексное влияние биологически активной кормовой добавки «Гумилид» и аскорбиновой кислоты на показатели оксидационного стресса и системы антиоксидантной защиты в крови лактирующих свиноматок и поросят в период от рождения до 21-суточного возраста. Установлено, что исследованные кормовые добавки вызывают снижение содержания гидропероксидов липидов, карбонильных групп протеинов и ТБК-активных продуктов, а также увеличение активности супероксиддисмутазы и каталазы в крови животных по отношению к контрольной группе. Сделан вывод о том, что кормовая добавка гуминовой природы совместно с витамином С повышает адаптационную способность организма как матерей, так и новорожденного молодняка, проявляют антистрессовые возможности и пролонгованное действие относительно животных, которые содержались на стандартном рационе.

Ключевые слова: свиноматки, поросята, критические периоды онтогенеза, адаптационная возможность организма, «Гумилид», аскорбиновая кислота.

Buchko Oksana. Free Radical Processes in the Pig's Organism Under the Influence of the Biologically Active Supplements. The paper deals with the problem of increasing of high performance animal's adaptive ability under the intensive technologies in the most critical moments - farrowing, lactation and birth. The influence of dietary food supplements «Humilid» with ascorbic acid on the free radical processes and antioxidant system parameters of lactating sows and their piglet's blood in the period from birth to 21 days have been studied. It has been shown that the using of feed supplements causes by reducing of lipid hydroperoxides concentration, protein carbonyl groups and TBA-active products, increasing of superoxide dismutase and catalase activities in the blood of animals compared to control group. It has been concluded that «Humilid» in the 
complex with vitamin $\mathrm{C}$ increases adaptive ability of the sows and their newborn piglets. These supplements characterized by antistress modulating properties and prolonged effect.

Key words: sows, piglets, critical periods of ontogenesis, adaptive ability of organism, «Humilid», ascorbic acid.

Стаття надійшла до редколегії 28.01.2015 p.

УДК 57.044:[616.018:616.348-022]

\author{
Марина Єна, \\ Галина Кузнєцова, \\ Наталія Дзюбенко, \\ Володимир Рибальченко
}

\title{
Вплив похідних піролу на слизову оболонку товстої кишки щурів, порівняно з глюкокортикоїдним препаратом, за умов розвитку експериментального коліту
}

Досліджено стан слизової оболонки нисхідної ободової кишки щурів за умов дії похідних піролу 5-аміно4-(1,3-бензотіазол-2-іл)-1-(3-метоксифеніл)-1,2-дигідро-3Н-пірол-3-ону (Д1) та 1-(4-Cl-бензил)-3-Cl-4-(CF феніламіно)-1Н-пірол-2,5-діон (МI-1), які характеризуються цитостатичною дією, протизапальними властивостями та не пошкоджують слизову оболонку товстої кишки щурів, про що свідчать отримані дані. Установлено, що MI-1 за умов індукованого експериментального коліту виявляє максимальний протизапальний та захисний ефект щодо слизової оболонки низхідної ободової кишки, тоді й захисна дія Д1 та комбінації Д1 і МІ-1 є значно слабшими. Сумісна дія похідних піролу із традиційним протизапальним засобом - преднізолоном відносно слизової оболонки низхідної ободової кишки при застосуванні за умов коліту є слабшою, порівняно 3 преднізолоном i, зокрема, із досліджуваними похідними піролу. При цьому в ряду преднізолон+МI-1, преднізолон+Д1, преднізолон+Д1+М1 протизапальна активність спадає.

Ключові слова: експериментальний коліт, преднізолон, похідні піролу, слизова оболонка низхідної ободової кишка.

Постановка наукової проблеми та її значення. Запальні захворювання кишечнику (ЗЗК), до яких традиційно належить виразковий коліт (ВК), - одна 3 найбільш серйозних проблем сучасної гастроентерології, що обумовлено їх постійно зростаючою поширеністю у всьому світі, хронічним, неухильно прогресуючим перебігом та ризиком кишкових і позакишкових ускладнень [1, 2]. Незважаючи на численні дослідження, етіологія ВК достеменно невідома. Серед їі причин називають спадковість, алергічні реакції, харчування, тривале застосування нестероїдних протизапальних засобів тощо [2, 3]. Наслідком хронічної форми ВК у більшості випадків може бути розвиток злоякісних новоутворень - колоректального раку $[1 ; 4 ; 5]$.

Перспективним здобутком для лікування злоякісних новоутворень є таргетні препарати, що вибірково діють на молекулярні мішені - ключові молекули сигнальних шляхів, які відповідають за передачу проліферативного сигналу, процеси апоптозу, контроль клітинного циклу та ін. Сьогодні вже доведено, що вказані засоби характеризуються високою протипухлинною активністю й значно меншою токсичністю, порівняно 3 класичними цитостатиками, а також мають протизапальні властивості $[4 ; 6 ; 7 ; 8]$.

До препаратів цього класу відносять похідні піролу 1-(4-Сl-бензил)-3-Cl-4-(CF 3 -феніламіно)-1Нпірол-2,5-діон (MI-1) та 5-аміно-4-(1,3-бензотіазол-2-іл)-1-(3-метоксифеніл)-1,2-дигідро-3Н-пірол-3он (Д1), синтезовані методом in silico дизайну Науково-виробничим хіміко-біологічним центром Київського національного університету імені Тараса Шевченка [9], що мають виражену цитостатичну дію, показану на лініях трансформованих [10] і ракових клітин [11-14]. Також установлено, що ці сполуки сприяють зменшенню запалення, що супроводжує розвиток раку, та оксидативного стресу [15, 16]. Отже, дослідження впливу похідних піролу на розвиток експериментального коліту є перспективним

(С Сна М., Кузнєцова Г., Дзюбенко Н., Рибальченко В., 2015 